\title{
Pengaruh Return On Assets(ROA) Dan return On Equity(ROE) terhadap Kinerja Kesehatan Capital Adequacy Ratio(CAR) Pada Bank BTPN
}

\author{
Harun Al Rasyid ${ }^{1}$, Suryanto Sosrowidigdo ${ }^{2}$ \\ Universitas Bina Sarana Informatika ${ }^{12}$ \\ harun.har@bsi.ac.id, suryanto.sys@bsi.ac.id
}

\author{
*Corresponding Author \\ Diajukan : 25 Desember 2021 \\ Disetujui : 1 Januari 2022 \\ Dipublikasi : : 4 Januari 2022
}

\begin{abstract}
Banking is currently being demanded to be able to increase its profitability because profitability is the net end result of various management policies and decisions. This ratio describes the level of effectiveness in managing banking assets if the profit generated by the bank is high it will also have an impact on own capital which can improve the health of the bank related to the Capital Adequacy Ratio $(C A R)$. The research method used is multiple linear regression analysis method. The type of research used is quantitative research. Source of data is secondary data. The data collection technique is a documentation technique. Data processing using SPSS 16. Data analysis used included descriptive test, classical assumption test, multiple linear regression test, hypothesis test, and coefficient of determination test. Hypothesis testing using t test shows that: 1) Return on Assets (ROA) has a positive and significant effect on the Capital Adequacy Ratio (CAR);2) Return On Equity (ROE) does not have a positive effect on the Capital Adequacy Ratio (CAR); and 3) the F test is known that simultaneously Return On Assets (ROA), Return On Equity (ROE) have a significant positive effect on the Capital Adequacy Ratio (CAR). Then the coefficient of determination (R2) is 0.172 or 17.2\%. This means that the contribution of Return On Assets (ROA), Return On Equity (ROE) to Bank BTPN's Capital Adequacy Ratio (CAR) is 84.1\%, while the remaining $15.9 \%$ is explained by other variables.
\end{abstract}

Keywords: Return On Asset (ROA), Return On Equity (ROE), Capital Adequacy Ratio (CAR).

\section{PENDAHULUAN}

Dalam pembangunan ekonomi diperlukan peran serta lembaga keuangan untuk membiayai, bank merupakan salah satu lembaga keuangan yang mempunyai peranan penting di perekonomian suatu negara dalam pembangunan ekonomi(Muzdalifa 2018). Bank adalah suatu badan usaha yang tugas utamanya sebagai lembaga perantara keuangan (financial intermediaries)(Rahmayeli 2018), untuk menyalurkan dana dari pihak yang berkelebihan kepada pihak yang membutuhkan dana atau kekurangan dana pada waktu yang ditentukan(Mawaddah 2015).

Menurut Undang-undang RI nomor10 Tahun 1998 tanggal 10 November1998 tentang perbankan yang dimaksud dengan perbankan adalah badan usaha yang menghimpun dana dari masyarakat dalam bentuk simpanan dan menyalurkannya kepada masyarakat dalam bentuk kredit dan dalam bentuk-bentuk lainnya dalam rangka meningkatkan tarap hidup orang banyak(Bachtiar Simatupang 2019).

Penilaian kesehatan bank sangat penting disebabkan karena bank mengelola dana yang dimilikinya setiap saat dan bank harus sanggup mengembalikan dana yang dipakainya jika ingin tetap dipercaya oleh nasabahnya(Christian 2017). Penilaian tingkat kesehatan bank mengacu pada Surat Edaran BI No.6/23/DPNP tanggal 31 Mei 2004 tentang Tata Cara Penilaian Kesehatan Bank dan Peraturan BI No.6/10/PBI/2004 tentang Sistem Penilaian Tingkat 
Kesehatan Bank Umum(Simatupang 2019). Adapun yang menjadi tolak ukur dasar penilaian kesehatan bank umum adalah penilaian faktor CAMELS yaitu permodalan(capital),kualitas asset(asset quality), manajemen (management), rentabilitas(earning), likuiditas (liquidity) dan sensitivitas terhadap risiko pasar(sensitivity to market risk)(Darmawan 2016).Bank perlu dinilai kesehatannya, tujuannya adalah untuk mengetahui kondisi bank tersebut yang sesungguhnya apakah dalam keadaan sehat(Sudarman Parenrengi 2018), kurang sehat, atau mungkin sakit. Apabila kondisi bank tersebut dalam kondisi sehat, maka perlu dipertahankan kesehatannya. Akan tetapi jika kondisinya dalam keadaan tidak sehat maka segera perlu diambil tindakan untuk mengobatinya. Dari penilaian kesehatan bank ini pada akhirnya akan ketahuan kinerja bank tersebut(Endah Tri Kurniasih 2020).

Rasio permodalan yang lazim digunakan untuk mengukur kesehatan bank adalah Capital Adequacy Ratio(CAR).Sesuai dengan SE BI No. 26/5/BPPtanggal 29 Mei 1993, besarnya Capital Adequacy Ratio(CAR) yang harus dicapaioleh suatu bank minima $18 \%$ sejak akhirtahun 1995. Tetapi karena kondisi perbankan nasional sejak akhir 1997terpuruk yang ditandai dengan banyaknya bank yang dilikuidasi, maka sejak Oktober tahun 1998 besarnya Capital Adequacy Ratio(CAR)diklasifikasikan ke dalam 3 kelompok. Klasifikasi bank sejak 1998 dikelompokkan dalam(Septyaningsih 2016) :

1. Bank sehat dengan kualifikasi A, jika memiliki Capital Adequacy Ratio(CAR) lebih dari $4 \%$.

2. Bank take over atau dalam penyehatan oleh BPPN (Badan Penyehatan PerbankanNasional) dengan klasifikasi B, jika bank tersebut memiliki Capital Adequacy Ratio(CAR) antara$25 \%$ sampai dengan $<$ dari $4 \%$.

3. Bank Beku Operasi (BBO) dengan klasifikasi C, jika memiliki Capital Adequacy. Ratio(CAR) kurang dari-25\%. Bank dalam kualifikasi $\mathrm{C}$ inilah yang mengalami likuidasi.Modal yang dimiliki bank untukmenunjang aktiva yang mengandung resiko.

Untuk saat iniminimal Capital Adequacy Ratio(CAR) sebesar 8\% dari Aktiva Tertimbang Menurut Resiko(ATMR),atau ditambah dengan Resiko Pasar dan Resiko Operasional, hal ini tergantung pada kondisi bank yang bersangkutan. Bank yang mempunyai CAR yang tinggi sangatlah baik karena bank ini mampu menanggung risiko yang mungkin timbul(Anggraeni 2018). Dengan adanya modal yang memadai bank dapat melakukan kegiatan operasionalnya secara lebihefisien melalui pengalokasian dana pada aset produktif yang memberikan keuntungan bagi bank dan risiko yang kecil(Murwani 2017). CAR yang tinggi menunjukkan semakin stabil usaha bank karena adanya kepercayaan masyarakat yang stabil. CAR dihubungkan dengan tingkat risiko bank. Semakin kecil risiko suatu bank maka semakin besar keuntungan yang diperoleh bank. Sejak periode krisis sampai dengan saat ini Capital Adequacy Ratio(CAR)menjadi acuan utama dalam menentukan kesehatan bank (SK Dir BI, April 1999).Hal ini juga disebabkan karena rata-rata Capital Adequacy Ratio(CAR) selama periode krisis sampai dengan akhir 2001 hanya mencapai 4\% dan sejak awal 2002 bank diwajibkan memenuhi Capital Adequacy Ratio(CAR) minimal 8\%. Kebijakan ini berawal dari kebijakan bank dunia (World Bank) yang ditindaklanjuti oleh pihak Bank Indonesia dengan kebijakan 29 Mei 1993 (PakMei,1993). Besarnya CAR minimal 8\% tersebut berlaku bagi seluruh bank secara internasional.Kinerja perbankan nasional yang buruk dianggap berperan terhadap munculnya krisis moneter diIndonesia.Salah satu ukuran untuk melihat kinerja perbankan adalah melalui Capital Adequacy Ratio(CAR). Pemilihan variable Capital Adequacy Ratio(CAR) sebagai variabel dependen dikarenakan Capital Adequacy Ratio(CAR) merupakan indikator yang paling penting menurut Bank Indonesia dalam menjaga tingkat kesehatan bank

Rentabilitas adalah salah satu aspek penilaian kesehatan bank dilihat dari kemampuannya dalam menciptakan laba, dua diantaranya adalah return on assets (ROA) dan return on equity (ROE)(Kurniasari 2017). ROA merupakan kemampuan bank dalam menghasilkan laba sebelum pajak atas kepemilikan aset. Sedangkan, ROE adalah kemampuan bank dalam menghasilkan laba setelah pajak atas pengelolaan modal. Berdasarkan uraian di atas penulis ingin mengetahui pengaruh rentabilitas dengan menggunakan return on assets (ROA) dan return on equity (ROE) terhadap rasio permodalan dengan menggunakan capital adequacy ratio (CAR) Pada PT. Bank 
BTPN.

\section{Penelitian Terdahulu}

\section{STUDI LITERATUR}

Di dalam melakukan suatu penelitian, maka diperlukan suatu landasan teori yang akan dipergunakan untuk mendukung teori-teori yang diuji. Salah satu landasan dapat digunakan sebagai acuan adalah dengan menggunakan penelitian terdahulu yang pernah dilakukan oleh pihak lain. Berikut adalah penelitian terdahulu yang dipandang bagus dan dapat dijadikan pendukung dalam penelitian ini :

1. Penelitian dari F. Agathya Sukmana, yang berjudul Pengaruh Return On Equity Return On Asset Net Interest Margin Dan Loan To Deposit Ratio Terhadap CAR Pada Perusahaan Perbankan Yang Terdaftar Di Bursa Efek Indonesia Tahun 2013-2015 yang bertujuan untuk mengetahui bagaimana kemempuan perusahaan perbankan dalam menghasilkan keuntungan dan mengelola serta mengalokasikan sumber daya yang dimiliki. Penelitian tersebut menggunakan analisis regresi berganda sehingga dapat diketahui bahwa (1) ROA, ROE, dan LDR secara parsial berpengaruh signifikan terhadap CAR pada perusahaan perbankan yang terdaftar di Bursa Efek Indonesia, sedangkan NIM secara parsial tidak berpengaruh signifikan terhadap CAR pada perusahaan perbankan yang terdaftar di Bursa Efek Indonesia. (2) ROA, ROE, NIM, dan LDR secara simultan berpengaruh signifikan terhadap CAR pada perusahaan perbankan yang terdaftar di Bursa Efek Indonesia. Persamaan dengan penelitian ini bahwa beberapa variabel bebasnya menggunakan ROA dan ROE serta variabel terikat yaitu CAR, sedangkan perbedaanya terletak pada objek penelitiannya(Sukmana 2017).

2. Penelitian dari F.Artin Shitawati dengan judul Analisis Faktor-Faktor Yang Berpengaruh Terhadap Capital Adequacy Ratio (Studi Empiris : Bank Umum di Indonesia periode 2001 2004) yang bertujuan untuk menguji pengaruh variabel ROA, ROE, NIM, BOPO, LDR, GWM terhadap CAR. Metode dalam penelitian tersebut menggunakan analisis regresi linier berganda sehingga didapatkan hasil bahwa ROA, ROE, NIM, LDR, BOPO dan GWM secara parsial berpengaruh signifikan terhadap CAR pada bank umum di Indonesia periode $2001-2004$ dengan nilai probabilitas kesemuanya lebih kecil dari 0,05 . Sementara secara bersama-sama ROA, ROE, NIM, BOPO, LDR dan GWM terbukti berpengaruh. Persamaan dengan penelitian ini bahwa beberapa variabel bebasnya menggunakan ROA dan ROE serta variabel terikat yaitu CAR, sedangkan perbedaanya terletak pada objek penelitiannya(F.artin shintawati 2016).

3. Tujuan penelitian dari Sugeng Riad ini adalah untuk mengetahui apakah Dana Pihak Ketiga (DPK), Non Performing Loan (NPL), Capital Adequacy Ratio (CAR), Loan to Deposit Ratio (LDR), Return On Asset (ROA), Net Interest Margin ( NIM), dan Beban Operasional Pendapatan Operasional berpengaruh terhadap penyaluran kredit pada bank pembangunan daerah di Indonesia. Objek dalam penelitian ini adalah bank pembangunan daerah di Indonesia tahun 2010-2014 (26 bank). Metode pengumpulan data adalah data historis dengan teknik analisis data yaitu analisis regresi linier berganda. Sedangkan uji hipotesis menggunakan uji t untuk menguji pengaruh variabel secara parsial dan uji $\mathrm{F}$ untuk menguji pengaruh variabel secara simultan. Hasil penelitian menunjukkan bahwa secara simultan semua variabel independen (DPF, NPL, CAR, LDR, ROA, NIM dan BOPO) berpengaruh terhadap variabel dependen (pemberian pinjaman). Hasil penelitian menunjukkan bahwa secara parsial Dana Pihak Ketiga (DPK), Loan to Deposit Ratio (LDR), Capital Adequacy Ratio (CAR) dan Return on Assets (ROA) berpengaruh positif dan signifikan terhadap penyaluran kredit. Variabel Beban Operasional Pendapatan Operasional berpengaruh negatif signifikan terhadap portofolio kredit, sedangkan variabel Non Performing Loan (NPL) tidak berpengaruh terhadap penyaluran kredit. Variabel independen yang paling dominan berpengaruh terhadap penyaluran kredit BPD di Indonesia adalah Dana Pihak Ketiga (DPK)(Riadi 2018).

\section{Pendekatan Penelitian}

\section{METODE}


Pendekatan penelitian mempergunakan penelitian Kuantitatif, karena penelitian ini menggunakan data statistik berupa angka-angka yang didapatkan dari data sekunder laporan keuangan. Jenis penelitian mempergunakan penelitian deskriptif. Penelitian deskriptif adalah penelitian yang dilaksanakan untuk memahami nilai variabel mandiri, baik satu variabel atau lebih (independen) tanpa membuat perbandingan atau menyambungkan antsara satu variabel dan variabel lainnya. Analisis deskriptif ini bertujuan untuk menghasilkan deskripsi, pemaparan atau narasi secara terstruktur, benar, dan saksama mengenai sifat-sifat serta korelasi antar fenomena yang diteliti.

\section{Kerangka Penelitian}

Kerangka penelitian adalah konsep pada penelitian yang saling berhubungan, dimana penggambaran variabel satu dengan lainnya bisa terkoneksi secara detail dan sistematis. Hal tersebut dilakukan agar penelitian bisa lebih mudah dipahami karena nantinya dalam laporan penyampaiannya bisa runtut(Riadi 2018).

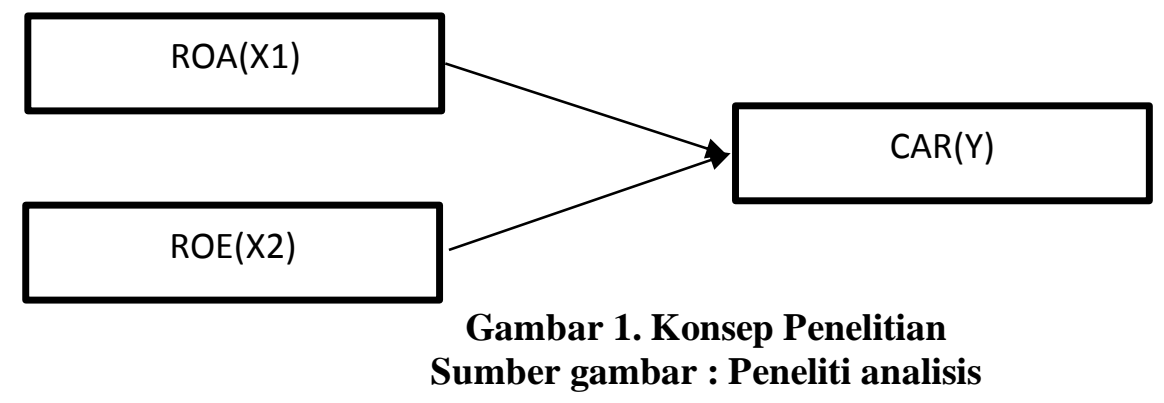

Pada Gambar 1. Pada penelitian kinerja kesehatan Bank BTPN, variabel yang digunakan yaitu: $\mathrm{ROA}(\mathrm{X} 1)$ dan Variabel $\mathrm{ROE}(\mathrm{X} 2)$ sebagai variable bebas(independent) dan variable CAR(Y) sebagai variable terikat(dependent).

\section{Hipotesis Penelitian}

Hipotesis penelitian berhubungan variabel $\mathrm{ROA}(\mathrm{X} 1)$ dan $\mathrm{ROE}(\mathrm{X} 2)$ dan variabel $\mathrm{CAR}(\mathrm{Y})$, dengan prediksi hasil penelitian sebagai berikut :

H1 : Ada pengaruh secara parsial ROA(X1) pada CAR(Y) kinerja kesehatan Bank BTPN pada periode $2015-2019$.

$\mathrm{H} 2$ : Ada pengaruh secara parsial $\mathrm{ROE}(\mathrm{X} 2)$ pada $\mathrm{CAR}(\mathrm{Y})$ kinerja kesehatan Bank BTPN pada periode $2015-2019$.

$\mathrm{H} 3$ : Ada pengaruh secara simultan $\mathrm{ROA}(\mathrm{X} 1)$ dan $\mathrm{ROE}(\mathrm{X} 2)$ pada $\mathrm{CAR}(\mathrm{Y})$ kinerja kesehatan Bank BTPN pada periode 2015 - 2019.

\section{Populasi dan Sampel Penelitian}

Populasi merupakan kesatuan yang mempunyai karakteristik yang sama dimana sampel akan kita tarik. Populasi dalam penelitian ini adalah dengan laporan tahunan BTPN dari tahun 2015 - 2019 yang berhubungan dengan Kinerja Kesehatan Bank BTPN.

Fokus penelitian Laporan Keuangan.Tahunan BTPN Tbk.Periode 2015-2019 yang Analisis rasio keuangan bank yang cocok dan berhubungan dengan regulasi Kinerja Kesehatan perbankan Indonesia Rasio.Rentabilitas (Return On Asset, Return On Equity) Rasio Solvabilitas (Cash Adequacy Ratio).

Analisis data mengulas data keuangan dari laporan keuangan tahunan yang berkaitan dengan PT BTPN .pada tahun 2015-2019. Bagian laporan yang digunakan rasio keuangan Bank BTPN. Rasio rentabilitas dan solvabilitas pada laporan keuangan. Dengan metode time series analysis, lakukan perbandingan hasil kalkulasi rasio keuangan setiap tahun. Menafsirkan nilai rasio yang telah dikalkulasi dan membandingkannya dengan tolak ukur peringkat komposit Otoritas Jasa Keuangan untuk menghitung kinerja keuangan Bank BTPN. 


\section{Uji Asumsi Klasik}

\section{Uji Normalitas}

Menjelaskan uji normalitas, yakni melaksanakan pengukuran terkait normal ataukah tidaknya data dalam variabel berdistribusi.Model regresi yang baik yakni mempunyai nilai residual yang terdistribusi normal(Wijaya 2021).

\section{Uji Multikolinieritas}

Menjelaskan, multikolinieritas yakni kondisipada metode regresi dimana berlangsung hubungan yang hampir sempurna ataupun bahkan sempurna antar variable independen. Tidak terdapatnya multikolinearitas merupakan prasyarat yang perlu dipenuhi pada model regresi. Uji yang dilaksanakan dalam melihat terdapat ataupun tidaknya gejala multikolinearitas yakni melalui memeriksa nilai VIF serta Tolerance. Apabilanilai VIF dibawah 10,00 serta nilai Tolerance melebihi 0,100(Wijaya 2021).

\section{Uji Autokorelasi}

Menjelaskan, uji autokorelasi dilaksanakan guna melaksanakan uji terkait adanya kesalahan penggangu pada model regresi terhadap periode $t$ dengan kesalahan pengganggu dalam periode t1 (sebelum), dimana yang baik yakni regresi yang terbebas oleh autokorelasi. Pendeteksian terdapatnya autokorelasi pada penelitian ini melalui uji Run Test(Wijaya 2021).

\section{Uji Heteroskedastisitas}

Uji ini tujuannya yakni mengetahuiada tidaknya ketidak sesuaian varians pada residual pengamatan satu terhadap pengamatan lainnya. Regresi yang sesuai syarat yakni ada kesesuaian varians dari residual pengamatan satu terhadap pengamatan yang lain sama ataupun dianggap heteroskedastitass, dimana yang dipergunakan meliputi(Wijaya 2021):

1. Memeriksa grafik plot diantara nilai prediksi variable dependen ataupun terikat yakni ZPRED dengan residual DRESID.

2. Pengujian park mengusulkan guna regresi nilai LnU2i selaku variable dependen.

\section{Model Analisi Data Penelitian}

Model analsisis data ini menggunakan analisis regresi berganda dalam mengecek pengaruh variabel independen (bebas) serta variabel dependen (terikat). Analisis data dalam pengelolaan data mempergunakan SPSS. Adapun rumus analisis regresi linier berganda meliputi(Wijaya 2021):

$$
\mathrm{Y}=\mathrm{a}+\mathrm{b} 1 \mathrm{X} 1+\mathrm{b} 2 \mathrm{X} 2+\mathrm{b} 3 \mathrm{X} 3+\mathrm{b} 4 \mathrm{X} 4+\mathrm{e}
$$

Keterangan:

$\mathrm{Y}=\mathrm{CAR}$

$\mathrm{a}=$ Konstanta

b1, b2, b3, b4= Keadaan Regresi

$\mathrm{X} 1=$ Variabel ROA

$\mathrm{X} 2$ = Variabel ROE

$\mathrm{e}=$ Estimasi Kesalahan $(0,05)$

\section{Uji Koefisien Determinasi $\left(\mathbf{R}^{2}\right)$}

menjelaskan, R2 ditunjukkan dalam menilai jauhnya kapabilitas model untuk menjabarkan variasi terikat. Apabila R2semakin tinggi ataupun dekat dengan 1, artinya kapabilitas variabel bebas $(\mathrm{X})$ yakni besar pada variabel terikat $(\mathrm{Y})$.

\section{Uji Signifikan Parsial (Uji-t)}

Menjelaskan, uji Statistik t memperlihatkan sejauh apa pengaruh variabel bebas/penjelas dengan individual untuk menjabarkan variasi variabel terikat.Pelaksanaan uji $\mathrm{t}$ yakni melalui memperbandingkan nilai statistik $\mathrm{t}$ pada titik kritis dalam tabel. Bila nilai statistik $\mathrm{t}$ perhitungan melebihi nilai t tabel, artinya variabel bebas dengan individual berpengaruh pada variabel terikat, dengan kriteria meliputi: 
Owner: Riset \& Jurnal Akuntansi

e-ISSN : 2548-9224|p-ISSN : 2548-7507

Volume 6 Nomor 1, Januari 2022

H (a )ditolak ataupun H_(o )diterima apabila nilai sig $>0,05$ serta thitung $\leq$ ttabel

H_(0 )ditolak ataupun H_(a )diterima apabila nilai sig $<0,05$ serta thitung $<$ ttabel

\section{Uji Koefisien Secara Simultan(Uji-F)}

Menuturkan, uji statistik F menyampaikan apa seluruh semua variabel yang masuk pada model ataupun variabel bebas berpengaruh dengan bersamaan pada variabel terikat. Dipergunakan statistik $F$ melalui kriteria penentuan keputusan melalui perbandingan nilai $F$ hasil perhitungan pada nilai F tabel, yaitu(Wijaya 2021):

H_a ditolak ataupun $\mathrm{H} \_$o diterima apabila nilai sig $>0,05$ serta Fhitung $\leq$ Ftabel

H_o ditolak ataupun $\mathrm{H}_{-}$a diterima apabila nilai sig $<0,05$ serta Fhitung $>$ Ftabel

\section{HASIL}

Hasil pengolahan data digambarkan secara umum melalui pendeskripsian data dengan statistik deskriptif. Pendeskripsian data dilakukan dengan nilai minimum, maksimum, mean, dan standar deviasi untuk tiap-tiap variabel.

Tabel 1. Statistik Deskriptif

\begin{tabular}{|l|r|r|r|}
\hline \multicolumn{3}{|c|}{ Descriptive Statistics } \\
\hline & \multicolumn{1}{|c|}{ Mean } & $\begin{array}{c}\text { Std. } \\
\text { Deviation }\end{array}$ & N \\
\hline CAR (Y) & 287.800 & 320.829 & 5 \\
\hline ROA(X1) & 24.820 & .60388 & 5 \\
\hline ROE (X2) & 106.400 & 172.569 & 5 \\
\hline
\end{tabular}

Sumber Tabel: Pengolahan data SPSS 2022

Tabel 1. tersebut menggambarkan statistik deskriptif dari 9 perusahaan yang bergerak dibidang pertambangan yang terdaftar di Bursa Efek Indonesia (BEI). Data tersebut diambil pada periode lima tahun, yaitu mulai tahun 2010 sampai 2014

\section{Uji Asumsi Klasik}

\section{Uji Normalitas}

Normalitas pengujian ini untuk membuktikan normalnya ataupun tidaknya data penelitian ini. Adapun normalitas statistik dengan pengukuran one-samplekolmogorov smirnov dengan sig. di atas 0,05 berarti normal. Pengujian yakni :

Tabel 2.One-Sample Kolmogorov Smirnov

\begin{tabular}{|l|l|r|}
\hline \multicolumn{2}{|c|}{ One-Sample Kolmogorov-Smirnov Test } \\
\hline & & \multicolumn{1}{|c|}{$\begin{array}{l}\text { Unstandardized } \\
\text { Residual }\end{array}$} \\
\hline $\mathrm{N}$ & & 0,0000000 \\
\hline $\begin{array}{l}\text { Normal } \\
\text { Parameters }\end{array}$ & Mean & \\
\hline & $\begin{array}{l}\text { Std. } \\
\text { Deviation }\end{array}$ & 0,90543706 \\
\hline
\end{tabular}


Owner: Riset \& Jurnal Akuntansi

e-ISSN : 2548-9224|p-ISSN : 2548-7507

Volume 6 Nomor 1, Januari 2022

DOI : https://doi.org/10.33395/owner.v6i1.634

\begin{tabular}{|l|l|r|}
$\begin{array}{l}\text { Most } \\
\text { Extreme } \\
\text { Differences }\end{array}$ & Absolute & 0,216 \\
\hline & Positive & 0,216 \\
\hline & Negative & $-0,163$ \\
\hline Test Statistic & & 0,216 \\
\hline $\begin{array}{l}\text { Asymp. Sig. } \\
\text { (2-tailed) }\end{array}$ & & $.200^{\text {c,d }}$ \\
\hline
\end{tabular}

Sumber Tabel: Pengolahan data SPSS 2022

Pada Tabel 2. Berdasarkan hasil Uji normalitas One-Sample Kolmogorov Smirnov, diketahui nilai signifikansi 0,200 > 0,05, maka dapat disimpulkan bahwa nilai residual berdistribusi normal.

\section{Uji Multikolinearitas}

Multikolinearitas diuji masih terdapatkah korelasi pada variabel independennya. Kriterianya VIF $<10$ dan tolerance $>0,1$.

Tabel 3. Hasil Uji Multikolinearitas

\begin{tabular}{|c|c|c|c|c|}
\hline \multicolumn{5}{|c|}{ Coefficientsa } \\
\hline Model & & Sig. & $\begin{array}{l}\text { Collinearity } \\
\text { Statistics }\end{array}$ & \\
\hline & & & Tolerance & VIF \\
\hline 1 & (Constant) & .016 & & \\
\hline & $\mathrm{ROA}(\mathrm{X} 1)$ & .041 & .249 & 4.018 \\
\hline & ROE (X2) & .062 & .249 & 4.018 \\
\hline a Dependent Variable: CAR (Y) & & & & \\
\hline
\end{tabular}

Sumber Gambar : Pengolahan data SPSS 2022

Pada Tabel 3. berdasarkan Uji Multikolinearitas, untuk nilai VIF 4,018< 10 pada $\mathrm{ROA}(\mathrm{X} 1), \mathrm{ROE}(\mathrm{X} 2)$ dan nilai Tolerance $0,249>0,1$ pada $\mathrm{ROA}(\mathrm{X} 1), \mathrm{ROE}(\mathrm{X} 2)$, maka disimpulkan tidak ada gejala multikolinearitas.

\section{Uji Autokorelasi}

Berdasarkan keputusan Uji Runs Test meliputi 2 kondisi, yaitu :

1. Jika nilai Asymp.Sig(2-tailed) < dari 0,05 maka terdapat gejala autokorelasi.

2. Jika nilai Asymp.Sig(2-tailed) $>$ dari 0,05 maka tidak terdapat gejala autokorelasi

Tabel 4. Hasil Uji Runs Test

\begin{tabular}{|l|r|}
\hline \multicolumn{2}{|c|}{ Runs Test } \\
\hline & $\begin{array}{l}\text { Unstandardized } \\
\text { Residual }\end{array}$ \\
\hline Test Value & $-0,26785$ \\
\hline Cases < Test Value & 2 \\
\hline Cases >= Test Value & 3 \\
\hline Total Cases & 5 \\
\hline Number of Runs & 4 \\
\hline Z & 0,109 \\
\hline Asymp. Sig. (2-tailed) & 0,913 \\
\hline a. Median & \\
\hline
\end{tabular}

Sumber Tabel : Pengolahan data SPSS 2022 
Owner: Riset \& Jurnal Akuntansi

e-ISSN : 2548-9224|p-ISSN : 2548-7507

Volume 6 Nomor 1, Januari 2022

DOI : https://doi.org/10.33395/owner.v6i1.634

Pada Tabel 4. Berdasarkan proses hasil uji Runs Test, diketahui nilai Asymp.Sig(2-tailed) sebesar $0,913>0,05$, maka tidak terdapat gejala autokorelasi.

\section{Uji Heteroskedastisitas}

Heterokedastisitas diuji untuk mengetahui adanya ataupun tidaknya persamaan varian dalam satu pengamatan terhadap pengamatan lainnya. Heteroskedastisitas dengan scatterplot grafiknya:

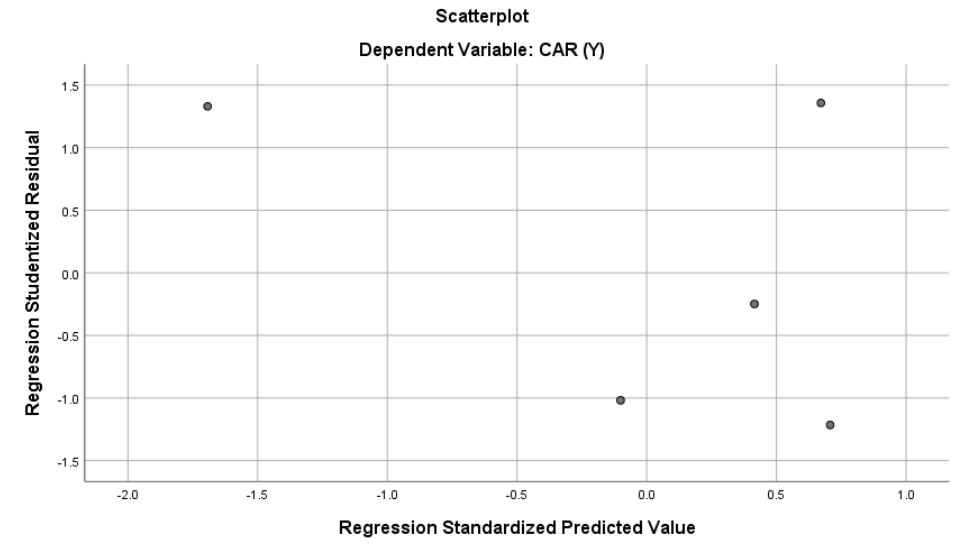

Gambar 2. Scatterplot Dependet Variabel CAR

Sumber Gambar : Pengolahan data SPSS 2022

Berdasarkan Gambar 2. terlihat titik menyebar dengan mengacak serta tidak menyusun pola sehingga tidak mengandung heteroskedastisitas.

Tabel 5. Uji Park

\begin{tabular}{|c|c|c|c|c|c|c|c|c|}
\hline \multicolumn{9}{|c|}{ Coefficients $^{\mathbf{a}}$} \\
\hline \multirow[b]{2}{*}{ Model } & & & & $\begin{array}{l}\text { Standardized } \\
\text { Coefficients }\end{array}$ & $\mathrm{t}$ & Sig. & $\begin{array}{c}\text { Collinearity } \\
\text { Statistics }\end{array}$ & \\
\hline & & & & \multirow[t]{2}{*}{ Beta } & \multirow[b]{2}{*}{7,914} & \multirow[b]{2}{*}{0,016} & \multirow[t]{2}{*}{ Tolerance } & \multirow[t]{2}{*}{ VIF } \\
\hline 1 & (Constant) & 33,962 & 4,291 & & & & & \\
\hline & ROA(X1) & 10,136 & 2,125 & 1,908 & 4,770 & 0,041 & 0,249 & 4,018 \\
\hline & ROE (X2) & $-2,852$ & 0,744 & $-1,534$ & $-3,835$ & 0,062 & 0,249 & 4,018 \\
\hline
\end{tabular}

Sumber Tabel : Pengolahan data SPSS 2022

Berdasarkan Tabel 5 terlihat keseluruhan variabel $\mathrm{ROE} 0,062>0,05$ tidak terjadi heteroskedastisitas.

\section{Hasil Analisis Data}

\section{Koefisien Determinasi $\left(\mathbf{R}^{2}\right)$}

$\mathrm{R}^{2}$ membuktikan seberapakah besar pengaruh variabel independennya pada dependen. Pengujiannya yakni :

Tabel 6. Koefisien Determinasi $\left(\mathrm{R}^{2}\right)$

\begin{tabular}{|c|c|c|c|c|c|}
\hline \multicolumn{6}{|c|}{ Model Summary ${ }^{b}$} \\
\hline Model & $\mathrm{R}$ & $\begin{array}{l}\mathrm{R} \\
\text { Square }\end{array}$ & $\begin{array}{l}\text { Adjusted } \\
\mathrm{R} \\
\text { Square }\end{array}$ & $\begin{array}{l}\text { Std. Error of } \\
\text { the Estimate }\end{array}$ & $\begin{array}{l}\text { Durbin- } \\
\text { Watson }\end{array}$ \\
\hline 1 & $.959^{\mathrm{a}}$ & 0,920 & 0,841 & 1,28048 & 1,711 \\
\hline
\end{tabular}


Owner: Riset \& Jurnal Akuntansi

e-ISSN : 2548-9224|p-ISSN : 2548-7507

Volume 6 Nomor 1, Januari 2022

\section{b. Dependent Variable: CAR (Y)}

Sumber Tabel : Pengolahan data SPSS 2022

Berdasar pada Tabel 6, nilai adjusted R Square (R2) 0,841(84,1\%). variabel independen berpengaruh pada tingkat kesehatan Bank BTPN sejumlah $84,1 \%$, serta 15,9\% sisanya terpengaruh variabel lainnya.

\section{Pengujian Hipotesis Uji t Parsial}

Dasar Pengambilan keputusan Uji t Parsial vberdasarkan nilai signifikansi ,jika nilai Sig $<0,05$ maka artinya variable independent $(\mathrm{X})$ secara parsial berpengaruh terhadap variable dependent $(\mathrm{Y})$

Tabel 7. Uji t Parsial

\begin{tabular}{|c|c|c|c|c|c|c|c|c|}
\hline \multicolumn{9}{|c|}{ Coefficients $^{\mathrm{a}}$} \\
\hline \multirow[b]{2}{*}{ Model } & & & & $\begin{array}{l}\text { Standardized } \\
\text { Coefficients }\end{array}$ & $\mathrm{t}$ & Sig. & $\begin{array}{l}\text { Collinearity } \\
\text { Statistics }\end{array}$ & \\
\hline & & & & \multirow[t]{2}{*}{ Beta } & & & Tolerance & VIF \\
\hline 1 & (Constant) & 33,962 & 4,291 & & 7,914 & 0,016 & & \\
\hline & $\operatorname{ROA}(X 1)$ & 10,136 & 2,125 & 1,908 & 4,770 & 0,041 & 0,249 & 4,018 \\
\hline & ROE (X2) & $-2,852$ & 0,744 & $-1,534$ & 3,835 & 0,062 & 0,249 & 4,018 \\
\hline
\end{tabular}

Sumber Tabel : Pengolahan data SPSS 2022

Pada Tabel 7. Berdasarkan hasil Uji t Parsial, meliputi beberapa hasil keputusan, diantaranya:

1. ROA (X1) berpengaruh secara parsial terhadap CAR(Y), karena nilai Sig. 0,041<0,05

2. $\operatorname{ROE}(\mathrm{X} 2)$ tidak berpengaruh secara parsial terhadap CAR(Y), karena nila Sig 0,062>0,05

\section{Pengujian Hipotesis Secara Simultan (Uji Statistik F)}

Dasar keputusan hipotesis hasil pengujiannya dijabarkan dalam Uji Statistik F secara simultan.Jika nilai Fhitung > Ftabel, maka variable independent $(\mathrm{X})$ secara simultan berpengaruh terhadap variable dependent $(\mathrm{Y})$. Rumus mencari Ftabel $=(\mathrm{k} ; \mathrm{n}-\mathrm{k})$

Tabel 8. Uji Statistik F

\begin{tabular}{|l|l|r|r|r|l|l|}
\hline \multicolumn{7}{|c|}{ ANOVA $^{\mathrm{a}}$} \\
\hline Model & & $\begin{array}{l}\text { Sum of } \\
\text { Squares }\end{array}$ & df & $\begin{array}{l}\text { Mean } \\
\text { Square }\end{array}$ & F & Sig. \\
\hline 1 & Regression & 37.893 & 2 & 18.947 & 11.555 & $.080 \mathrm{~b}$ \\
\hline & Residual & 3.279 & 2 & 1.640 & & \\
\hline & Total & 41.173 & 4 & & & \\
\hline \multicolumn{7}{|l}{ a Dependent Variable: CAR (Y) } \\
\hline
\end{tabular}

Sumber Tabel : Pengolahan data SPSS 2022

Pada Tabel 8. terlihat Fhitung 11,555, nilai signifikan 0,080 dan Ftabel (2:3) yakni sejumlah 9,55 didapati kesimpulan meliputi Fhitung > Ftabel yakni 11,555>0,108 dengan keputusan Ha diterima serta Ho ditolak, artinya ROA,ROE, berpengaruh terhadap CAR dalam Bank BTPN periode dari tahun 2015 sampai dengan 2019.

\section{PEMBAHASAN}

Pembahasan hasil dari proses pengolahan data dengan aplikasi SPSS, dengan model regresi 
linear berganda, meliputi hasil analisa :

1. Analisis Pengaruh ROA terhadap CAR

Return On Assets (ROA) merupakan rasio yang digunakan untuk mengukur kemampuan Bank BTPN dalam menghasilkan laba yang berasal dari aktivitas investasi. Dari analisis diatas dan dengan melihat tabel 7, maka hasil uji t dari data tersebut adalah sebagai berikut : ROA berpengaruh positif terhadap CAR. ROA berpengaruh signifikan terhadap CAR atau dengan kata lain, ROA adalah indikator suatu unit usaha untuk memperoleh laba atas sejumlah asset yang dimiliki oleh unit usaha tersebut. Rasio ini digunakan untuk mengukur kemampuan manajemen dalam memperoleh keuntungan secara keseluruhan. Semakin besar ROA, semakin besar pula tingkat keuntungan yang dicapai oleh Bank BTPN tersebut dan semakin baik pula posisi Bank BTPN tersebut dari segi penggunaan asset. Sehingga hipotesis yang berbunyi Secara signifikan ada pengaruh Return On Assets terhadap Capital Adequacy Ratio di Bank Bank BTPN yaitu teruji.

\section{Analisis Pengaruh ROE terhadap CAR}

Return On Equity (ROE) merupakan ukuran kemampuan bank dalam menghasilkan keuntungan dengan menggunakan modal sendiri, sehingga ROE ini sering disebut sebagai rentabilitas modal sendiri. Dari analisis diatas dan dengan melihat tabel 7, maka hasil uji t dari data tersebut adalah sebagai berikut : ROE tidak berpengaruh terhadap CAR. Return On Equity (ROE) atau hasil pengembalian atas ekuitas merupakan rasio yang menunjukkan seberapa besar kontribusi ekuitas dalam menciptakan laba bersih. Dengan kata lain, rasio ini digunakan untuk mengukur seberapa besar jumlah laba bersih yang akan dihasilkan dari setiap rupiah dana yang tertanam dalam total ekuitas. Rasio ini dihitung dengan membagi laba bersih terhadap ekuitas.

3. Analisis Pengaruh ROA, ROE terhadap CAR

Pengaruh ROA dan ROE secara simultan terhadap tingkat kesehatan bank, pada CAR sangatlah baik kemampuan dalam mengolah labah bersih dari aktivitas investasi dengan kinerja yang baik dalam manajemen investasi yang masuk dari pihak eksternal. Untuk ROE perlu adanya peningkatan kinerja kesehatan Bank BTPN dalam menghasilkan keuntungan dengan menggunakan modal sendiri.. Berdasar pada Tabel 6, nilai adjusted R Square (R2) 0,841 $(84,1 \%)$. variabel independen berpengaruh pada tingkat kesehatan Bank BTPN sejumlah $84,1 \%$, serta $15,9 \%$ sisanya terpengaruh variabel lainnya. CAR menunjukan kemampuan bank dalam penyediaan dana yang digunakan untuk mengatasi resiko kerugian. Batas aman untuk CAR adalah $8 \%$, semakin tinggi tingkat CAR maka semakin bagus kemahiran bank dalam mengatasi kerugian.

Penelitian ini selaras dengan teori Pandia, semakin besar Return On Assets suatu bank, maka semakin besar tingkat keuntungan bank dan semakin baik pula posisi bank dari segi aset. 2 Return On Asset merupakan rasio yang digunakan untuk mengukur kemampuan perusahaan dalam menghasilkan laba yang berasal dari aktivitas investasi. Atau dengan kata lain, Return On Assets adalah indikator suatu unit usaha untuk memperoleh laba atas sejumlah asset yang dimiliki oleh unit usaha tersebut. Rasio ini digunakan untuk mengukur kemampuan manajemen dalam memperoleh keuntungan secara keseluruhan.Return On Asset (ROA) juga digunakan untuk menilai sejauh mana investasi yang telah ditanamkan mampu memberikan pengembalian keuntungan sesuai dengan yang diharapkan. Dan investasi tersebut sebenarnya sama dengan asset perusahaan yang ditanamkan atau ditetapkan.

\section{KESIMPULAN}

Berdasarkan hasil penelitian yang telah dilakukan terkait dengan pengaruh Return On Assets, dan Return On Equity terhadap Capital Adequacy Ratio Bank Syariah Mandiri maka dapat ditarik kesimpulan sebagai berikut:

1. Berdasarkan hasil pengujian hipotesis kesatu(H1) diketahui bahwa secara parsial Return On Assets berpengaruh positif dan signifikan terhadap Capital Adequacy Ratio Bank BTPN 20152019. Pengaruh Return On Assets yang positif terhadap Capital Adequacy Ratio dapat terjadi karena pertumbuhan aktiva produktif sangat baik yang menyebabkan kebutuhan pembentukan cadangan untuk mengantisipasi resiko yang terjadi sejalan dengan optimalisasi produktivitas 
asset, sehingga kecukupan permodalan Bank BTPN yang digambarkan oleh CAR mengalami Kenaikan.

2. Berdasarkan hasil pengujian hipotesis kedua(H2) diketahui bahwa secara parsial Return On Equity tidak berpengaruh positif terhadap Capital Adequacy Ratio Bank BTPN 2015-2019. Dapat disimpulkan bahwa setiap penurunan Return On Equity akan menaikkan Capital Adequacy Ratio Bank BTPN. Dan sebaliknya, setiap Kenaikan Return On Equity Kenaikan Capital Adequacy Ratio Bank BTPN.

3. Berdasarkan pengujian hipotesis ketiga (H3) diketahui bahwa secara simultan Return On Assets dan Return On Equity berpengaruh positif dan signifikan terhadap Capital Adequacy Ratio Bank BTPN. Maka setiap terjadi peningkatan pada variabel Return On Assets, dan Return On Equity akan berdampak pada peningkatan Capital Adequacy Ratio Bank BTPN.

\section{REFERENSI}

Anggraeni, Luluk. 2018. "Pengaruh Financing Deposite Ratio (FDR), Capital Adequacy Ratio (CAR), Dan Biaya Operasional Pendapatan Operasional (BOPO) Terhadap Return On Asset (ROA) Pada Bank Syariah Mandiri Tahun 2013-2017." reposit Uni. mercu buana yogyakarta.

Bachtiar Simatupang. 2019. “ASPEK YURIDIS UU NO.10 TAHUN 1998 TERHADAP PERANAN PERBANKAN DALAM MENINGKATKAN PEREKONOMIAN INDONESIA BERDASARKAN PANCASILA DAN UUD 1945." Ensiklopedia Social Revie 1(1): 1-9.

Christian, Frans Jason. 2017. "Analisa Kesehatan Bank Dengan Menggunakan Metode RGEC Pada Bank BRI Dan Mandiri Periode 2012-2015.” Jurnal EMBA 5(2): 530-40.

Darmawan, Rizky Achmad. 2016. "Penilaian Tingkat Kesehatan Bank Dengan Metode Camel (Studi Kasus Pada PT. BPR. Manuk Wari Tamanan).” REPOSITORY UM JEMBER 1: 172.

Endah Tri Kurniasih. 2020. "Analisis Kinerja Keuangan PT. Bank Perkreditan Rakyat (BPR) Mitra Lestari Terhadap Tingkat Kesehatan Perbankan." Ekonomis: Journal of Economics and Business 4(2): 369.

F.artin shintawati. 2016. "ANALISIS FAKTOR-FAKTOR YANG BERPENGARUH TERHADAP Capital Adequacy Ratio (Studi Empiris : Bank Umum Di Indonesia Periode 2001 - 2004)." reposit undip.

Kurniasari, Rani. 2017. "Analisis Return On Assets (ROA) Dan Return On Equity Terhadap Rasio Permodalan (Capital Adequacy Ratio) Pada PT Bank Sinarmas Tbk.” Jurnal Moneter 4(2): 150-58. Analisis Return On Assets (ROA) dan Return On Equity Terhadap Rasio Permodalan (Capital Adequacy Ratio) Pada PT Bank Sinarmas Tbk.

Mawaddah, Nur. 2015. "FAKTOR-FAKTOR YANG MEMPENGARUHI PROFITABILITAS BANK SYARIAH." Jurnal Etikonomi 14(September): 241-56. http://journal.uinjkt.ac.id/index.php/etikonomi.

Murwani, Juli. 2017. "Pengaruh Manajemen Modal Kerja Terhadap Profitabilitas Bank Perkreditan Rakyat (Bpr) Di Madiun, Magetan, Ngawi Dan Ponorogo.” Assets: Jurnal Akuntansi dan Pendidikan 5(2): 89.

Muzdalifa, Irma. 2018. "Peran Fintech Dalam Meningkatkan Keuangan Inklusif Pada UMKM Di Indonesia (Pendekatan Keuangan Syariah).” Jurnal Masharif al-Syariah: Jurnal Ekonomi dan Perbankan Syariah 3(1).

Rahmayeli. 2018. “Analisis Kinerja Keuangan Pada Pt. Bank Perkreditan Rakyat (Bpr) Batang 
Owner: Riset \& Jurnal Akuntansi

e-ISSN : 2548-9224 |p-ISSN : 2548-7507

Volume 6 Nomor 1, Januari 2022

DOI : https://doi.org/10.33395/owner.v6i1.634

Kapas Pesisir Selatan.” : 1-7.

Riadi, Sugeng. 2018. "The Effect of Third Parties Fund, Non Performing Loan, Capital Adequacy

Ratio, Loan to Deposit Ratio, Return On Assets, Net Interest Margin and Operating

Expenses Operating Income on Lending (Study in Regional Development Banks in Indonesia)." Proceedings of the International Conference on Industrial Engineering and Operations Management 2018-March: 1015-26.

Septyaningsih. 2016. "DETERMINAN PROFITABILITAS BANK SYARIAH DI

INDONESIA(Periode 2010-2016)." e-print.

Simatupang, Bachtiar. 2019. "Peranan Perbankan Dalam Meningkatkan Perekonomian Indonesia.” Jurnal Riset Akuntansi Multiparadigma 6(2): 136-46.

Sudarman Parenrengi. 2018. "Pengaruh Dana Pihak Ketiga, Kecukupan Modal Dan Penyaluran Kredit Terhadap Profitabilitas Bank.” ejournal.imperiuminstitute.org/1(1): 9-18.

Sukmana, F A. 2017. "Pengaruh Return On Equity, Return On Asset, Net Interest Margin Dan Loan To Deposit Ratio Terhadap CAR Pada Perusahaan Perbankan Yang Terdaftar Di ...." Simki-Economic Volume 01 No. 11 Tahun 2017 ... 01(11).

http://simki.unpkediri.ac.id/mahasiswa/file_artike1/2017/cfa08644b0b74721f3abf58abc5cda f5.pdf.

Wijaya, Nevin. 2021. "Pengaruh Modal Kerja,Total Hutang,Tingkat Inflasi Dan Penjualan Bersih Terhadap Laba Bersih." Owner 5(1): 240-51. 